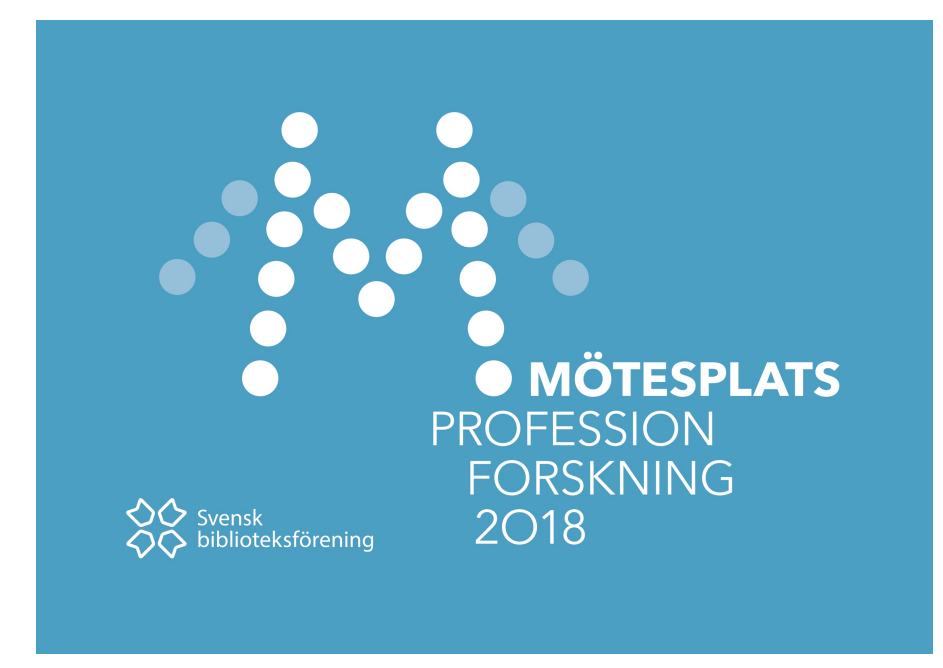

\begin{tabular}{c} 
Viktoria Reuterskiöld \\
$\begin{array}{c}\text { Grindtorpsskolan, Botkyrka kommun } \\
\text { viktoria.reuterskiold@botkyrka.se }\end{array}$ \\
\hline
\end{tabular}

\title{
Skarpt läge - värderingar och vägval vid hantering av kontroversiella föredrag på bibliotek
}

\section{Inledning och problemformulering}

När personer eller organisationer med kontroversiella budskap vill framträda på bibliotek kräver detta ett ställningstagande från ledningen. I Sverige finns idag ingen självklar samsyn kring vilka budskap som bör tillåtas på folkbiblioteken, tvärtom går åsikterna ofta isär. Intervjuer med bibliotekspersonal visar på ett upplevt dilemma mellan målet om bredast möjliga utbud och uppdraget att verka för mångfald och inkludering (Söderlind och Elf, 2014). Vid flera tillfällen har det uppstått problem kring kontroversiella föredrag. Ett exempel är Karl Olov Arnstbergs föreläsning Invandring och mörkläggning som ett fåtal dagar innan framträdandet i Göteborg ställdes in av säkerhetsskäl, på grund av demonstrationer och bråk utanför biblioteket. Beslutet fick senare kritik för att vara ett grundlagsbrott (Westin, 2016, Wetterqvist, 2016). Ett annat exempel är den invandrings- och islamkritiska samhällsdebattören Jan Sjunneson som vid två tillfällen har fått lov att hålla föredrag på Uppsala stadsbibliotek. Att biblioteket upplät lokaler åt föredragen medförde protester från allmänheten och kritik i lokalpressen eftersom föredragshållarens budskap ansågs vara islamfientligt och antidemokratiskt. (Bergström, 2015, Sterner, 2018).

Beslut kring kontroversiella föredrag på bibliotek aktualiserar samma frågor som beslut om inköp av kontroversiella medier men innebär ofta större utmaningar. En kontroversiell bok kan ställas ner i källaren eller i en avsides hylla men en talares budskap hörs i hela lokalen och det exakta innehållet är ofta oklart i förväg. Med en tillåtande policy gentemot kontroversiella föredrag riskerar biblioteken att upprörda känslor och motreaktioner väcks i publiken. I Norge har det starka värnandet om yttrandefriheten gjort att särskilt kontroversiella föredrag har tillåtits på biblioteken, trots kraftfulla protester från allmänheten. Exempelvis fick den svenske konstnären Lars Vilks hålla ett stödföredrag för konstnären Dan Park som i sin tur har hyllat attentatsmannen Anders Bering Breivik som sköt ihjäl 69 ungdomar på ett sommarläger i Norge. Bibliotekschefen Kristin Danielsen 
förklarade beslutet med uttalandet: "Vi håller yttrandefriheten högt" (Grahn, 15 oktober, 2014). Vilks har däremot nekats att hålla föredrag på svenska bibliotek sedan länge med hänvisning till säkerhetsskäl (Degerholm, 2007).

Beslut kring kontroversiella föredrag på bibliotek berör ytterst frågan om det demokratiska samhället gynnas eller missgynnas av att sådana budskap ges utrymme i offentliga rum. Föredrag som hålls i bibliotekens lokaler uppfattas dessutom ofta som del av bibliotekens verksamhet. Bibliotekschefer och programansvariga måste därför fråga sig: Vad händer om besökare vänder i dörren därför att en talare tycks dem alltför motbjudande att lyssna till, eller vad händer när vissa intressen och åsikter inte tillåts framträda i lokalerna? Hur ska uppdraget tolkas och vad ska värderas högst; yttrandefrihet och fri åsiktsbildning eller ansvar och hänsynstagande.

Denna artikel presenterar en analys av fem djupintervjuer med bibliotekschefer från 2016 som syftar till att belysa de ideologiska ställningstaganden som ligger bakom chefernas resonemang och hantering av kontroversiella föredrag på bibliotek. För att uppnå studiens syfte har följande frågor formulerats:

Hur hanterar folkbiblioteken kontroversiella talare och hur anser bibliotekschefer och programansvariga att de ska hanteras med hänsyn till yttrandefriheten och bibliotekens uppdrag? Vad innebär bibliotekens uppdrag när det gäller programverksamhet, enligt informanterna och hur ser de på bibliotekets roll som offentlig arena och plats för debatt?

\section{Tidigare forskning}

Historiskt har frågan om åsiktsfrihet behandlats av exempelvis John Stuart Mill i verket $O m$ Friheten från 1869. Liksom många efter honom såg Mill ett tydligt dilemma i frågan. Han förespråkar fri åsiktsbildning och religionsfrihet men skriver också att det civiliserade samhället måste bevara en anda av god medborgerlighet, vilket kan kräva maktmedel för att hindra människor att skada varandra. Gränsen för friheten bör gå där skada tillfogas.

Förutom överväganden kring vad som gynnar det goda samhället finns en annan viktig faktor som kan påverka bibliotekens förhållningssätt kring kontroversiella budskap - den allmänna opinionen. Byrne (2004) menar att lokalsamhällets önskemål och påtryckningar lätt kan glida över i censur. Som exempel nämner han de krav som restes i många länder på att Harry Potter-böckerna skulle tas bort från biblioteken för att de innehåller magi, vilket ogillades av en del kristna grupper. Han förespråkar en tillåtande policy och påpekar att det som anses kontroversiellt av majoritetssamhället kan vara det enda som intresserar enskilda individer.

Oltmann (2016) redovisar en studie av amerikanska bibliotekariers syn på censur och yttrandefrihet. Den visade att en överväldigande majoritet var starkt för yttrandefrihet och motståndare till censur samt uppgav att de sympatiserade med American Library Associations Freedom to Read Statement (ALA, 2016). Samtidigt svarade så många som 40 procent att de hade upplevt konflikt mellan sina personliga värderingar och de professionella (Oltmann, 2016, s. 40). Moody (2004) är också emot censur men lyfter samtidigt fram de stora svårigheterna att handskas med exempelvis rasistiska, homofobiska och antisemitiska budskap. Doyle (2008) skriver att attentat liksom det som skedde den 11 september $2001 \mathrm{i}$ USA hotar yttrandefriheten och det fria samhället, vilket är ett skäl att kämpa för dess bevarande. Samtidigt, konstaterar han, vill knappast någon bibliotekarie bidra till att sätta 
instruktionsböcker för vapentillverkning i händerna på terrorister. En som försvarar censur och bortval är den amerikanske filosofen John Rawls (1999) som menar att det finns lägen då en demokratiskt vald stat måste sätta stopp för material som hotar medborgarna och dess egen existens.

Amerikanen Ronald B. Mc Cabe (2001), själv bibliotekarie, beskriver hur en frihetlig konsensus växte fram kring bibliotekens uppdrag i USA på 80-talet, tvärtemot den tidigare synen där biblioteken tog på sig uppgiften att utbilda demokratiska medborgare. Resultatet av de nya tankeströmningarna blev ett uppdrag som endast handlar om att tillgängliggöra information. I Sverige har en liknande utveckling skett, från en tydlig folkbildande ambition i bibliotekens barndom mot en som huvudsakligen handlar om informationsspridning (Hansson, 1995). McCabe (2001) är kritisk till att utbildningsuppdraget övergavs och menar att enbart informationsförmedling är en alltför banal uppgift för dagens välutbildade bibliotekarier. De har kompetens nog för att göra urval och bör göra sådana. Biblioteket bör återta sin roll som utbildare av goda medborgare genom att främja demokratiska budskap och värderingar, anser McCabe (2001). Den nu rådande intellektuella och moraliska relativismen härleder han tillbaka till romantikens attack på upplysningen. För att lyfta fram individuell frihet förnekades rationell kunskap och tanken på gemensamma moraliska värden som kan delas av alla i ett samhälle. Men för att ett samhälle ska fungera, krävs det att man kan enas kring vissa grundläggande värderingar och det var i upprätthållandet av sådana värderingar som biblioteken från början såg sin roll (McCabe 2001).

Folkbiblioteken som fysiska rum inrymmer naturligtvis många möjligheter. Den starka betoningen av folkbibliotekens roll som medborgerlig mötesplats är enligt Hvenegaard Rasmussen et al. (2013, s.52) en "global trend" inom biblioteksväsendet. Exempelvis SkotHansen (2004) framhåller bibliotekens potential som platser där människor ställs inför andra synsätt och värderingar än de egna. Att sådana platser existerar är viktigt eftersom ömsesidig tolerans är centralt i en demokrati, påpekar både Skot-Hansen (2001) och Audunson (2004). Skot-Hansen (2001) anser också att biblioteken mister sin roll i den offentliga debatten om de undviker aktuella, kontroversiella frågor och bara har trivselföredrag av typen reseskildringar eller föredrag om kända personer. Även andra nordiska forskare, såsom Ankersen (2004) och Vestheim (1999) skriver att biblioteken bör vara arenor för debatt som innefattar kontroversiella ämnen.

\section{Teoretiska utgångspunkter}

Teorier och begrepp som har använts vid analysen av intervjumaterialet har främst hämtats från Joacim Hanssons licenciat-avhandling Om folkbibliotekens ideologiska identitet: en diskursstudie (1995) och Emily Knox artikel Intellectual Freedom and the AgnosticPostmodernist View of Reading Effects (2014). Begreppet ideologi används i betydelsen; ett sätt att tänka, vilket innefattar värderingar och normer som placerar en handling i en kontext och gör den meningsfull (Hansson, 1995, s.35). Begreppet kontroversiell är allmänt känt och syftar här på åsikter som kan upplevas som upprörande och stötande. Det kan exempelvis handla om åsikter där vissa samhällsgrupper pekas ut som problematiska eller skildras på ett sätt som kan uppfattas som nedsättande. Ordet extrem används främst i meningen anti-demokratisk och syftar på åsikter och värderingar som i regel ligger utanför de som majoritetssamhället har. 
Hansson (1995) undersöker alltså vilka underliggande idéer och politiska strömningar som utgör grunden för folkbibliotekens ideologiska identitet. Utvecklingen av folkbiblioteken fick fart under den allmänna folkbildningsrörelsen som uppstod under tidigt 1900-tal. Från liberalt, borgerligt håll förespråkades det att biblioteket skulle vara en politiskt neutral organisation som kunde ansvara för någon form av bildningsarbete genom att tillgängliggöra god litteratur, till skillnad från dålig. Inom dessa gränser fick litteraturen lov att vara underhållande. Här dök alltså tanken på att biblioteken bör vara neutrala upp redan under tidigt 1900-tal, en tanke som återkommer hos några av informanterna i denna studie. Det fanns dock en oro för att den så kallade "smutslitteraturen" skulle fördärva ungdomen. Litteraturen fick också gärna gagna ett nationalistiskt tänkesätt. Vikten av kritiskt tänkande som ofta betonas idag, talades det inte heller om.

Det som gör att åsikterna om folkbibliotekens uppgift skiljer sig åt inom olika organisationer, är, enligt Hansson (1995), människosynen. Inom nykterhetsrörelsen, som stod bakom de så kallade sockenbiblioteken, fanns en syn på individen som aktiv, myndig och kapabel till egna val. På dessa bibliotek eftersträvades bredd i utbudet, även litteratur som främst var roande skulle finnas med. Det viktigaste var att främja läslusten. Sockenbiblioteket skulle vara något annat än skolbiblioteken och snarare bidra till ökad förståelse i samhället än att fostra. Ett brett utbud ansågs alltså gynna en tolerant samhällsanda. Hos den tidiga arbetarrörelsen framträder däremot en syn på individen som underkastad de kollektiva mål som rörelsen arbetar mot. Till en början hade rörelsen egna bibliotek och deras bildningssyn hade ett tydligare uppfostrande inslag än hos de liberala. Trots att arbetarrörelse- och studiecirkelbiblioteken verkade ha bättre förutsättningar för att utgöra grund till ett kommunalt biblioteksväsen, blev det sockenbiblioteken som utgjorde den ideologiska grunden. Orsaken var att de som på central nivå utarbetade styrdokumenten hade en konservativ bildningssyn som främst betonade ett traditionellt bildningsideal, bevarande av traditioner och läsfrämjande (Hansson, 1995).

Knox (2014) tydliggör vilka ideologier som ligger bakom synen på kunskapens natur och dess effekter på individer och samhället. Hon identifierar en traditionell, modernistisk syn på kunskap och dess effekter. Enligt detta synsätt leder läsning av god litteratur till att människor blir bättre, utvecklar goda karaktärer och beter sig väl, vilket i sin tur bidrar till ett bättre samhälle. På samma sätt skapar läsning av dålig litteratur sämre människor och kan i förlängningen skada hela samhället. Denna inställning bottnar, enligt Knox, i en tid då många bibliotekarier såg det som sin uppgift att vara moralens väktare och skydda medborgarna från fiktionslitteratur till förmån för mera uppbygglig litteratur. Uppfattningen att god litteratur ger bättre människor med bättre värderingar kan härledas tillbaka till upplysningen (McCabe, 2001) och stämmer överens med arbetarrörelsens inställning till kunskap (Hansson, 1995).

Knox (2014) identifierar också en postmodernistisk kunskapssyn. Denna medger att kunskap som görs tillgänglig kan få konsekvenser men att det är omöjligt att förutsäga vilka dessa blir, varken för individer eller för samhället. Hon skriver att denna inställning intar en agnostisk hållning i förhållande till effekterna av kunskap. Enligt den postmodernistiska kunskapssynen ligger meningen i en text hos den som tolkar den och därför går det inte att veta hur den kommer att uppfattas eller påverka läsaren. Enligt Knox (2014) är det den postmodernistiska kunskapssynen som tillåter bibliotekarier att verka för yttrandefriheten. 
Denna kunskapssyn har alltså, enligt McCabe (2001), rötter som går tillbaka till romantiken och dess betoning på individuell frihet.

De av Knox (2014) presenterade två olika synsätten på kunskap går i linje med de två synsätt på bibliotekens uppgift som Hansson (1995) identifierar i sin licentiatavhandling om bibliotekens ideologiska identitet. Det ena synsättet kan summeras som en ansvarstagande, fostrande, modernistisk syn där biblioteken genom urval försöker påverka människor och samhällets utveckling i önskad riktning. Historiskt förespråkades detta synsätt av arbetarrörelsen men även i viss mån av liberaler och konservativa. Det andra synsättet är av mer agnostisk karaktär, med en friare, postmodern syn, där biblioteken låter användarna stå för tolkningen av olika budskap. Ett synsätt som är mer i linje med hur nykterhetsrörelsen såg på kunskap och kunskapsförmedling.

Dessa två ideologiskt olika sätt att se på bibliotekens roll och uppgift kommer att användas i analysen för att tydliggöra bibliotekschefernas ställningstaganden kring kontroversiella föredrag. Jag har valt att kalla de två ideologiska ståndpunkter som identifierats ovan för det ansvarstagande och det frihetliga perspektivet. Syftet med analysen är att härleda resonemang och tankar kring kontroversiella föredrag på bibliotek till ideologiska ställningstaganden vilket gör dessa två perspektiv meningsfulla och användbara.

\section{Metod och genomförande}

Under februari till maj 2016 utfördes semistrukturerade intervjuer med fyra bibliotekschefer och en programansvarig bibliotekarie för att undersöka deras ideologiska förhållningssätt till kontroversiella föredrag (Reuterskiöld, 2016). Genom noggrann läsning och en tematisk innehållsanalys inspirerad av Lieblich et al. (1998) sållades intressanta teman fram med (jmf Bergström \& Boreaus, 2012). Ett annat möjligt angreppssätt hade varit att studera artiklar där bibliotekschefer uttalat sig kring kontroversiella föredrag men då skulle möjligheten till följdfrågor och förtydliganden inte ha funnits, vilket också gäller enkätundersökningar. Datainsamlingsmetoden anpassades efter analysmetoden, vilket ledde till ett öppet angreppssätt, utan på förhand fastslagna kategorier för att undvika en alltför styrd tolkning. Intervjufrågorna utformades för att synliggöra ståndpunkter och resonemang som går i linje med något av de två ideologiska perspektiv som identifierats i kapitlet teoretiska utgångspunkter.

Bibliotekscheferna identifierades genom artiklar i Biblioteksbladet och i svenska dagstidningar där de figurerade i samband med kontroversiella talare på bibliotek. Intervjuerna gjordes per telefon och samtalen spelades in och transkriberades. Varje intervju tog cirka 40 minuter. Intervjuguiden utformades kring två huvudsakliga teman; kontroversiella talare och biblioteket som offentlig arena. I den första delen av intervjuerna uppmanades informanterna berätta om en konkret erfarenhet kring en kontroversiell talare eller ett programinslag. Därefter följde några frågor kring bibliotekens demokratiska roll i samhället, som sökte svar på hur informanterna tolkar denna roll när det gäller programverksamhet. Slutligen ställdes frågor kring biblioteket som arena för debatt, hur en sådan roll kan hanteras samt eventuella problem med föredrag och debatter på bibliotek. Uttalanden som tydligt uttrycker värderingar har lyfts fram i analysen och kopplas till ideologiska ställningstaganden kring yttrandefrihet, hänsyn och bibliotekets uppdrag samt till det frihetliga respektive det ansvarstagande perspektivet. 
De intervjuade kallas vid fingerade namn som börjar på A, B, C, D och E. Endast en av dem var man så för att minska igenkänningsrisken har även han fått ett kvinnligt namn och refereras till som en hon. Namnen på orter skrivs inte ut och den av de intervjuade som inte var bibliotekschef, utan programansvarig, kallas också för bibliotekschef. En nackdel med metoden är att viktiga data kan gå förlorade eller förvrängas vid transkription av ljudfiler (Czarniawska, 2004, Lapadat \& Lindsay, 1999). Man kan naturligtvis ifrågasätta om tolkningen är trovärdig eftersom en läsning av materialet med andra utgångspunkter och perspektiv kan ge en annan tolkning. Detta behöver dock inte vara negativt. Ett postmodernistiskt synsätt vänder sig emot modernismens tro på kunskap som en spegel av verkligheten och bejakar istället en mångfald av berättelser och tolkningar av verkligheten (Kvale \& Brinkmann, 2014). Denna analys kan alltså ses som ett förslag på en, utifrån argumentation och val av teoretiskt perspektiv, rimlig och möjlig tolkning.

\section{Resultat och analys}

Vid närläsningen av den transkriberade texten utkristalliserade sig två tydliga teman. Det första temat kallar jag folkopinionens betydelse. Med folkopinion avses de åsikter som allmänheten i ett lokalsamhälle ger yttryck för eller antas ha. För bibliotekscheferna handlar det om att lyssna på, bedöma och väga in omgivningens behov och önskemål. Detta förhållningssätt kan leda till att kontroversiella budskap tillåts eller inte, beroende på om man ligger närmast ett frihetligt eller ett ansvarstagande perspektiv.

Samtliga intervjuade bibliotekschefer har påverkats av och försökt väga in lokalsamhällets syn på kontroversiella föredrag. Den allmänna opinionen fångas ofta upp och uttrycks $i$ medierna och flera av bibliotekscheferna har fått kritik i lokalpressen för sina beslut. Exempelvis ställde Dorotea in ett kontroversiellt föredrag till följd av protester och oroligheter utanför biblioteket. Föredraget innehöll ett invandringskritiskt budskap och föredragshållaren hade själv bokat in sig i bibliotekets lokaler. Till en början hade Dorotea inte tänkt neka inbokningen men ändrade sig på grund av folkopinionen. Anette sa vid ett tillfälle nej till att biblioteket skulle vara med och arrangera en föreläsning av en känd person eftersom innehållet i föreläsningen inte stämde överens med bibliotekets uppdrag, såsom det formulerades i den lokala biblioteksplanen. Detta ledde till kritik i press och annan media, både mot biblioteket, biblioteksplanen och mot Anette personligen, vilket hon upplevde som mycket jobbigt. Hennes personliga åsikt var att föredraget inte var kontroversiellt och därför var det extra påfrestande att tvingas försvara beslutet. Erika talar om att göra aktiva val präglade av det samhälle man verkar i, vilket kan leda till att föredrag väljs bort. Hon är medveten om att detta kan medföra kritik och påpekar att det finns en "laddning" i offentliga platser, att det pågår en ständig "strid" om vem som får synas där.

Carin valde efter långa och känslosamma interna diskussioner att tillåta ett kontroversiellt föredrag, vilket ledde till kritik från allmänhet och press. Hon upplevde både beslutsprocessen och kritiken som mycket jobbig och hade "oro och ont i magen". Hon var rädd för att bibliotekets rykte skulle skadas och oroade sig för säkerheten. Beatrice, som arbetar på ett landsortsbibliotek, har upplåtit biblioteket åt talare som inte "anses rumsrena av alla", som hon uttrycker det. Media uppmärksammade inte saken, men själv ville hon undvika hetsiga diskussioner och "smutskastning" mellan olika parter och bjöd därför in företrädare för olika åsikter varsin dag under en vecka. Någon debatt blev det alltså inte. Samtliga bibliotekschefer påverkades mycket av folkopinionen, inför sina beslut om 
kontroversiella föredrag. De flesta ansåg att bibliotekschefer bör tåla kritik men de som fått utstå känsloladdad intern debatt och kritik från allmänhet och media upplevde detta som mycket påfrestande och svårhanterligt. Det som slutligen avgjorde besluten var den egna ideologiska ståndpunkten där antingen fri åsiktsbildning eller ansvar och hänsyn prioriterades i tolkningen av uppdraget. Folkopinionen är alltså en viktig faktor vid beslutsfattande kring kontroversiella föredrag och bibliotekscheferna upplevde det som särskilt svårt när de på grund av ideologiska ställningstaganden eller lokala styrdokument såg sig tvingade att gå emot opinionen.

Nästa tema för analysen är fri åsiktsbildning respektive ansvar i relation till bibliotekens uppgift. Vikten av fri tillgång till information betecknades av bibliotekschefen Anette som en av bibliotekets "grundpelare". Hon uppger sig ha gått från ett normkritiskt perspektiv till att fokusera på tillgång till information men talar också om vikten av balans. Carin menar att biblioteken måste agera ansvarsfullt när det gäller budskap som inte gillas internt. Man får till exempel inte, som ibland förekommer, säga att det är fullbokat för att slippa en oönskad talare. Biblioteken ska, enligt Carin, inte censurera eller vara "åsiktspoliser" men om det står klart att ett budskap bryter mot lagen ska man säga nej till det. Carin önskar också en tydligare praxis kring hur kontroversiella föredrag ska hanteras på bibliotek men liksom Anette återkommer hon ständigt till vikten av att bidra till fri åsiktsbildning genom ett brett utbud av information. Även Beatrice vill att biblioteket ska vara en "demokratisk mötesplats" och anser att det är fel att välja bort budskap man ogillar genom att exempelvis tala om bristande kvalitet. Samtidigt kan det bli problem eftersom kvaliteten faktiskt kan vara bristande. Dorotea säger att det är mycket svårt att neka en kontroversiell talare såsom bibliotekens uppdrag är utformade i lagen och styrdokumenten. Samtidigt påpekar hon att biblioteket inte har resurser för att tillmötesgå alla önskemål. Säkerheten måste också beaktas anser hon. Dorotea problematiserar den vanliga skrivningen i svenska biblioteksplaner om att biblioteket ska vara "till för alla". I hennes stad har det varit debatt om stök och bråk på biblioteken. Dorotea påtalar att de som är högljudda och stökiga kanske inte känner sig välkomna och "kanske faktiskt inte heller är det". Hon betonar vikten av fri åsiktsbildning men också ansvaret för säkerheten. Erika avviker från de övriga genom att betona vikten av ett ansvarstagande förhållningssätt som det viktigaste. Erika betonar att värden som jämställdhet och jämlikhet är centrala i bibliotekens uppdrag och att det är viktigt vilka värden man förmedlar. "Ingenting är neutralt eller uppfattas som det", säger hon. Biblioteken ska enligt styrdokumenten prioritera mindre resursstarka grupper och deras intressen och biblioteksrummet bör utformas med hänsyn till det samhälle man verkar i. Erika avviker alltså från de fyra andra då hon betonar vikten av ansvar och jämställdhet betydligt mer än uppdraget att verka för informationsspridning och fri åsiktsbildning. Resultaten ovan hör samman med den första frågan i min frågeställning om hur biblioteken hanterar kontroversiella talare och hur man anser att de ska hanteras med hänsyn till yttrandefriheten och bibliotekens uppdrag.

Vad gäller frågan om biblioteken är lämpliga som arenor för debatt, såsom Skot-Hansen (2001) och Audunsen och Aabo (2004; 2012) framhåller, så resonerade bibliotekscheferna som följer: Carin anser att denna funktion kan och bör utvecklas betydligt mer och tillhör uppdraget. En allsidighet i utbudet är viktig men debatter ska hållas under kontrollerade former där alla sidor får göra sig hörda. Under sådana förhållanden kan även kontroversiella intressen medverka, anser hon. Anette uttrycker ungefär samma åsikter, att debatter passar 
bra på bibliotek och även bör kunna inrymma kontroversiella ämnen. Samtidigt anser hon att biblioteken ska ha "en armlängds avstånd till politiken", för att vara neutrala. Dorotea berättar att debatter har hållits vid ett flertal tillfällen på hennes bibliotek. Samtliga partier har deltagit och debatten har letts av en moderator. Ibland har det också varit enskilda politiker som diskuterat med varandra, "mera som samtal". Intresset för dessa programpunkter har varit stort och det har fungerat utan ordningsstörningar, enligt Dorotea.

Beatrice, som bjöd in ett parti i taget för att undvika "smutskastning", är trots sin försiktighet positiv till debatter på bibliotek. Hon påpekar själv att det verkar motstridigt eftersom hon undvek debatt genom att bjuda in olika partier varsin dag. Hon kan dock tänka sig att ordna debatter och även att leda sådana evenemang, säger hon. Erika menar att biblioteken redan i nuläget är arenor för debatt. "Det (biblioteket) är redan idag väldigt politiskt och det som uttrycks i böcker och program är inte neutralt", säger hon. Hon talar om att många intressen vill synas på bibliotek och tror att det kan uppfattas som en "legitimering" att få synas där. Det biblioteken tar in får en stämpel av att vara kunskap och viktigt, säger hon. Erika tycker dock att andra värden väger tyngre än att extrema och kontroversiella åsikter ska beredas plats på biblioteken.

\section{Diskussion}

I denna studie har det visat sig att fyra bibliotekschefers ställningstaganden går i linje med vad som i teoriavsnittet introducerades som det frihetliga perspektivet. Dessa chefer tycker inte det är bibliotekets uppdrag att skydda människor från kontroversiella budskap och betonar i första hand vikten av att verka för fri åsiktsbildning. Deras syn stämmer överens med Audunson (2004) som slår fast vikten av ömsesidig tolerans i en demokrati och att det finns platser där olika värderingar möts. Förespråkarna för det frihetliga perspektivet framhåller att det är möjligt och önskvärt för biblioteket att förhålla sig neutralt i förhållande till all information som det bereder plats för, vilket stämmer överens med en postmodernistisk hållning till kunskap och information (Knox (2014). De bibliotekschefer som ideologiskt ligger närmast detta perspektiv ligger också nära den svenska nykterhetsrörelsens tro på människans förmåga att göra egna val (Hansson, 1995). De som står nära det frihetliga perspektivet saknar dock inte ett ansvarsperspektiv, de ser förverkligandet av den fria informationsspridningen som ett tungt och viktigt ansvar.

Med ett ansvarstagande perspektiv avses dock en annan sorts ansvar som ligger i linje med den fostrande roll som biblioteket ofta tilldelades i sin barndom (Hansson, 1995). Detta ansvar stämmer också överens med modernismens idé om att god litteratur skapar goda människor (Knox, 2014). En bibliotekschef i denna studie uttrycker åsikter som står närmast det ansvarstagande perspektivet. Hon betonar vikten av jämlikhet och att skapa ett inkluderande rum som lyfter fram mindre priviligierade människors berättelser framför uppdraget att verka för fri åsiktsbildning och informationsspridning. Biblioteket bör aktivt välja vad som ska beredas plats i dess lokaler och därmed stå upp för de värden som slås fast i styrdokumenten. Detta kan ses som en strävan att stå för det goda och lyfta fram åsikter som ryms inom det demokratiska samhället, såsom McCabe (2001) förespråkar. Det ideologiska ställningstagandet, för det goda och mot det onda, som blir tydlig i det ansvarstagande perspektivet går i linje med de tankar som uttrycks av filosofen Rawls (1999) som poängterade att demokratin behöver skyddas från destruktiva krafter som vill krossa den. 
Denna studie utgör ett bidrag till diskussionen om yttrandefrihet kontra hänsynstagande på bibliotek med specifik inriktning på programverksamhet, dock bygger den endast på fem bibliotekschefers berättelser, vilket gör att några generella slutsatser inte kan dras. Naturligtvis kunde undersökningen ha gjorts på en mängd andra sätt, vilket kunde ha gett annorlunda resultat. All slags bibliotekspersonal kunde ha tillfrågats, liksom allmänheten. Med fler informanter kunde svaren ha jämförts utifrån parametrar som kön, skillnader mellan geografiska områden med mera. Studien har dock bidragit till att förtydliga de underliggande ideologiska värderingar som ligger bakom hantering av kontroversiella föredrag på bibliotek.

Både det frihetliga och det ansvarstagande perspektivet kan medföra svårigheter. Att besökare möts av kränkande budskap som inte stämmer överens med värdegrunden i biblioteksplanerna kan bli problematiskt. Rawls (1999) påpekar att jämlikhet uppstår först när alla har lika goda förutsättningar i samhället. Att som vit medelklass deklarera att människor inte ska skyddas från kränkande budskap är problematiskt då sådana budskap hittills nästan aldrig handlat om infödda svenskar från medelklassen. Det kan också hävdas med hänvisning till Rawls (1999), att företrädare för extrema intressen, som om de fick makten skulle avskaffa yttrandefriheten, själva har förbrukat sin rätt att använda den. Ett annat argument för en mera restriktiv linje är att det finns tal som är avsett att tysta andra människor, vilket kan användas som ett argument för att inte tillåta sådant tal (Bossaller och Budd, 2015). Till det frihetliga perspektivets försvar kan sägas att i ett mer totalitärt samhälle skulle mindre priviligierade grupper kanske inte få lov att yttra sig alls. Ju större yttrandefrihet, desto större möjlighet har även marginaliserade grupper att få göra sig hörda. Yttrandefriheten är på så vis en garant för allas röster på gott och ont.

För att problematisera det ansvarstagande perspektivet finns naturligtvis risken att det blir, som några av bibliotekscheferna uttrycker det, "ett sluttande plan" där man väljer bort mer och mer. Nedsättande budskap om exempelvis överviktiga, kvinnor eller karaktärer som avviker från allmänna normer går att finna i nästan all skönlitteratur. Liksom Audunsen (2004, s. 437) kan man hävda att: "the cement of democracy is tolerance". Asheim (1953) påpekar också att de skäl som ofta anges för bortval, exempelvis ekonomiska skäl eller att det inte passar målgruppen, ligger mycket nära de som skulle anges av en censurinstans. Till försvar för det ansvarstagande perspektivet kan man titta på konkreta exempel i stället för högtidliga deklarationer om yttrandefrihet. Intressanta frågor är exempelvis: Vill biblioteken sätta bombmanualer i händerna på terrorister (Doyle, 2008) och är det rätt att en nyanländ person som flytt till Sverige, med fara för sitt liv, på biblioteket ska mötas av budskapet att hen är oönskad?

Hittills har det ofta handlat om invandringskritiska budskap vars företrädare vill tala på bibliotek men naturligtvis kan det bli aktuellt att ta ställning till andra grupper, exempelvis politiska och religiösa grupper av olika slag och/eller grupper med en kvinnosyn som avviker kraftigt från västerländska värderingar. I bibliotekens uppdrag ingår utan tvekan att stå upp för demokratiska värden vilket kan tolkas som att alla budskap inte passar på bibliotek. Skulle yttrandefriheten dras till sin spets kanske biblioteken måste ha kontakt med organisationer som kan vara farliga (Bossaller \& Budd, 2015), vilket enligt min mening är helt orimligt. Samtidigt är bibliotekslagens skrivning om att bidra till fri åsiktsbildning (SFS 2013:801, § 2) mycket viktig, särskilt i en tid då yttrandefriheten är hotad i vår omvärld. 
Allteftersom de fysiska boklånen minskar är det också viktigt att fundera på hur bibliotekslokalerna ska användas i framtiden. Föredrag och debatter kan framöver ges ett större utrymme och fylla en viktig uppgift genom att bidra till exponering för och förmedling av olika slags åsikter. Skulle folkbiblioteken reduceras till tekniska mediaparker dit människor endast går för att låna en dator och skriva ut blanketter, så har de, enligt min mening, förlorat sin själ. Idén om att bidra till folkbildning stämmer alltjämt väl överens med uppdraget att verka för demokratin och bör också kunna samexistera med uppdraget att verka för fri åsiktsbildning, jämlikhet och hänsyn till utsatta grupper.

\section{Slutsatser}

Bibliotekschefernas berättelser om skarpa lägen då de varit tvungna att ta beslut, visar att det inte finns några givna svar på hur kontroversiella föredrag ska hanteras på bibliotek. De intervjuade cheferna har valt att hantera situationerna på olika sätt beroende på sina egna tolkningar av uppdraget och sina olika ideologiska ståndpunkter. Kontroversiella budskap väcker ofta starka känslor hos allmänheten och risken att få kritik är därför stor, oavsett vilket beslut som fattas. Bibliotekschefernas hantering av kontroversiella föredrag kommer att påverka människors uppfattning om biblioteken och vad de står för och är därför viktiga. Vilka budskap som passar på bibliotek kommer troligen att förbli ett ämne för diskussion mellan chefer och personal, vilket kan ses som ett demokratiarbete. Lokalsamhällets åsikter måste vägas in, liksom politik och allmänna värderingar i samhället i stort. Begreppet demokrati innefattar idag både yttrandefrihet och hänsyn till utsatta grupper och minoriteter, vilket gör att både det frihetliga och det ansvarstagande perspektivet kan hävdas vara i linje med bibliotekens roll som främjare av demokratin.

Flera av de intervjuade cheferna uttryckte intresse för att utveckla biblioteket som medborgerlig mötesplats och arena för debatt, eventuellt med kontroversiella inslag. Därför vore det intressant att undersöka hur besökare ställer sig till debatter på bibliotek och kontroversiella talares medverkan i sådana. Oavsett om man släpper fram kontroversiella föredrag eller inte, så är det möjligt att låta en utbyggd programverksamhet präglas av en folkbildande ambition på det sätt som McCabe (2001) föreslår. Detta kan komma att bli viktigt i framtiden om de fysiska boklånen och böckerna minskar. Föredrag, samtal och debatter kan då bidra till ett brett utbud av åsikter och kanske fylla en del av det tomrum de fysiska böckerna lämnar efter sig. 


\section{Källförteckning}

\section{Intervjuer med bibliotekschefer och en programansvarig:}

Intervju med "Anette", 2016-03-23

Intervju med "Beatrice", 2016-03-30

Intervju med "Carin", 2016-04-04

Intervju med "Dorotea", 2016-04-12

Intervju med "Erika", 2016-05-10

\section{Övriga källor:}

Ankersen, D. (2014, 10 oktober). Lars Vilks stödtalar för Breivik-hyllare. ETC. Hämtad 7 september, 2018, från http://www.etc.se/inrikes/lars-vilks-stodtalar-breivik-hyllare

Arnstberg, K-O \& Sandelin, G. (2013). Invandring och mörkläggning 1, en saklig rapport från en förryckt tid. Skärholmen: Debattförlaget.

Asheim, L. (1953). Not Censorship But Selection. Wilson Library Bulletin, vol. 28, s. 63-67. ALA (American Library Association).

Audunson, R. (2005). The public library as a meeting-place in a multicultural and digital context. The necessity of low-intensive meeting-places. Journal of Documentation, vol. 61, (3), s. 429-441.

Audunson, R. \& Svanhild, A. (2012). Use of library space and the library as place. Library \& Information Science Research, vol. 34, (2), s. 138-149

American Library Association, ALA, Hämtad 7 september, 2018, från http://www.ala.org/

Bergström, G. \& Boréus, K. (Red.) (2005). Textens mening och makt: metodbok $i$

samhällsvetenskaplig text- och diskursanalys. Lund: Studentlitteratur.

Bergström, K. (2015, 6 september). Islamfientlig debattör på stadsbiblioteket. Upsala Nya Tidning. Hämtad 3 september, 2018, från:_www.unt.se/kultur-noje/islamfientlig-debattorpa-stadsbiblioteket-3883216.aspx

Bossaller, J. S. \& Budd, J. M. (2015). Information, Community, Policy. What We Talk about When We Talk about Free Speech. Library Quarterly: vol. 85, (1), s. 26-44.

Byrne, A. (2004) The end of history: censorship and libraries. The Australian Library Journal, vol. 53, (2), s. 133-151.

Czarniawska, B. (2004). Narratives in social science research. London: Sage.

Degerholm, A. (2007, 4 september). Bibliotekschefen stoppar Vilks besök. Trelleborg Allehanda. Hämtad 7 september, 2018, från http://www.trelleborgsallehanda.se/newarticles/bibliotekschefen-stoppar-vilks-besok/ 
Doyle, T. (2008) Selection Versus Censorship in Libraries. Collection Management, vol. 27, (1), s. $15-25$.

Grahn, S. (2014, 15 oktober). Vilks stödtalar för Dan Park i Norge. SVT Nyheter Kultur. Hämtad 7 september, 2018, från http://www.svt.se/kultur/vilks-stodtalar-for-dan-park-inorge

Hansson, J. (1995). Om folkbibliotekens ideologiska identitet: en diskursstudie. Licentiatavhandling. Borås: Högskolan i Borås.

Hvenegaard Rasmussen, C., Jochumsen, H. \& SkotHansen, D. (2013). Biblioteket som mødested: Sociologisk legitimitet og inspiration fra byplanlægningen. Nordisk Tidsskrift for Informationsvidenskab og Kulturformidling, 2(1), s. 51-59.

Knox, Emily. (2014). Intellectual Freedom and the Agnostic-Postmodernist View of Reading Effects. Library Trends. vol. 63, (1), s. 11-26.

Kvale, S. \& Brinkmann, S. (2014). Den kvalitativa forskningsintervjun. Lund: Studentlitteratur.

Lapadat, J. C. \& Lindsay, A. C. (1999). Transcription in research and practice: From standardization to technique to interpretive positionings. Qualitative Inquiry, vol. 5, (1), s. 64-86.

Lieblich, A., Tuval-Mashiach, R. \& Zilber, T. (1998). Narrative Research: reading, analysis, and interpretation. Thousand Oaks. California: Sage Publications.

McCabe, R. B. (2001). Civic Librarianship - Renewing the Social Mission of the Public Library. Lanham: Scarecrow press.

Mill, J. S. (1859/2009). Om Friheten. Stockholm: Natur och Kultur.

Moody, K. (2004) Covert censorship in libraries: a discussion paper, The Australian Library Journal, vol.54, (2), s. 138-147.

Oltmann, M. S. (2016) Public Librarians' Views on Collection Development and Censorship. Collection Management, vol. 41, (1), s. 23-44.

Rawls, J. (1999). En teori om rättvisa. Göteborg: Daidalos.

Reuterskiöld, V. (2016), Skarpt läge - värderingar och vägval vid hantering av kontroversiella föredrag på bibliotek, Mastersuppsats, Högskolan i Borås.

SFS 1991:1469. Yttrandefrihetsgrundlag. Stockholm: Justitiedepartementet. Hämtad 7 september, 2018, från: http://www.riksdagen.se/sv/dokument-lagar/dokument/svenskforfattningssamling/yttrandefrihetsgrundlag-19911469_sfs-1991-1469

SFS 2013:801. Bibliotekslag (2013) Stockholm. Kulturdepartementet, Regeringskansliet. Hämtad 7 september, 2018, från: 
http://www.riksdagen.se/sv/DokumentLagar/Lagar/Svenskforfattningssamling/sfs_sfs-2013$801 /$

Skot-Hansen, D. (2001). Folkebiblioteket i civilsamfundet - civilsamfundet i folkebiblioteket. I Audunson, R. \& Windfeldt, N. (Red.). Det siviliserte informasjonssamfunn -folkbibliotekenes rolle ved inngangen til en digital_tid. s. 45-62. Bergen: Fagbokforlaget.

Sterner, G. (2018, 12 april). Kontroversiell debattör åter till Uppsala. Upsala Nya Tidning. Hämtad 3 september, 2018, från:_www.unt.se/kultur-noje/kontroversiell-debattor-ater-tilluppsala-4950287.aspx

Söderlind, Å. \& Elf, G. (2014). "Vi arbetar i medborgarnas tjänst": en kartläggning av mediestrategiskt arbete på bibliotek utifrån normerande dokument. Stockholm: Svensk biblioteksförening.

Tryckfrihetsförordning: SFS 1949:105 (1949). Hämtad 7 september, 2018, från: https://www.riksdagen.se/sv/dokument-lagar/dokument/svenskforfattningssamling/tryckfrihetsforordning-1949105_sfs-1949-105

Westin, A. (2016, 5 februari). Göteborg får JO-kritik för inställd föreläsning om invandring. Biblioteksbladet, (endast webbsidan). Hämtad 7 september, 2018, från http://biblioteksbladet.se/?s=g\%C3\%B6teborg+jo-kritik

Vestheim, G.(1999). Ideologi og folkebibliotekpolitikk - eit demokratispørsmål. I Amnå, E. \& Johannesson, L. (Red.), Demokratins estetik. Stockholm: Fakta info direkt.

Wetterqvist, A. (2016, 5 februari). Grundlagsbrott stoppa föreläsning om "invandring och mörkläggning" - JO kritisk. Dagens Juridik. Hämtad 7 september, 2018, från http://www.dagensjuridik.se/2016/02/grundlagsbrott-stoppa-forelasning-om-invandringoch-morklaggning-jo-kritisk 